УДК 616.34-002

DOI: 10.18101/2306-1995-2019-2-52-57

\title{
КЛИНИЧЕСКИЙ СЛУЧАЙ ЦЕЛИАКИИ У МУЖЧИНЫ 43 ЛЕТ
}

\section{(C) Спасова Татьяна Евгеньевна}

кандидат медицинских наук, доцент, кафедра поликлинической терапии и профилактической медицины с курсом ОЗиЗ, Бурятский государственный университет им. Д. Банзарова Россия, 670000, г. Улан-Удэ, ул. Смолина, 24а

E-mail: tspasova@inbox.ru

\section{(C) Халтагарова Екатерина Дмитриевна}

старший преподаватель, кафедра поликлинической терапии и профилактической медицины с курсом ОЗиЗ, Бурятский государственный университет им. Д. Банзарова Россия, 670000, г. Улан-Удэ, ул. Смолина, 24а

E-mail: tspasova@inbox.ru

\begin{abstract}
Представлен клинический случай поздней диагностики целиакии у мужчины 43 лет. Симптомы заболевания проявлялись с детства, однако заболевание не диагностировали. В возрасте 40 лет наступило ухудшение состояния с выраженными проявлениями синдрома мальабсорбции. Целиакия подтверждена данными эндоскопического обследования, повышением титра аутоантител в сыворотке крови и положительным эффектом аглютеновой диеты.

Ключевые слова: целиакия, аглютеновая диета, антиглиалиновые антитела, синдром мальабсорбции.

Для цитирования:

Спасова Т. Е., Халтагарова Е. Д. Клинический случай целиакии у мужчины 43 лет // Вестник Бурятского государственного университета. Медицина и фармация. 2019. Вып. 2. С. 52-57.
\end{abstract}

Целиакия - это патология тонкой кишки у генетически предрасположенных людей любого возраста, при которой происходит непереносимость продуктов, содержащей глютен, что вызывает развитие иммунопатологических процессов в тонкой кишке, нарушения мембранного пищеварения и всасывания питательных веществ [2]. Диагноз целиакии устанавливается при наличии следующих признаков. Во-первых, при гистологическом исследовании слизистой тонкой кишки обнаруживаются атрофические изменения желез в виде уменьшения и укорочения ворсинок, лимфоплазмоцитарной инфильтрацией собственной пластинки слизистой оболочки. При длительном и тяжелом течении заболевания может происходить метаплазия зрелых энтероцитов в малодифференцированные клетки. Во-вторых, происходит увеличение титра антиглиадиновых антител в сыворотке крови больных, а именно AEMA (антиэндомизиальные антитела), AGA IgG и А (антиглиадиновые антитела), Anti-tTG (антитела к тканевой трансглутаминазе). В-третьих, отмечается 
положительный терапевтический эффект аглютеновой диеты, $\mathbf{y}$ больных наблюдается регресс клинической симптоматики и восстановление структуры слизистой оболочки кишечника.

Распространенность целиакии в мире среди здорового населения имеет разные показатели и варьирует с частотой 1:100 - 1:200 [1]. Актуальность заболевания связано с тем, что отношение диагностируемых случаев целиакии к недиагностированным в Европе составляет 1:5-1:13. При поздней диагностике заболевания у больных в 5 раз повышается риск развития злокачественных заболеваний, таких как аденокарцинома толстой кишки, злокачественные лимфомы, опухоли тонкого кишечника, ротоглоточные опухоли. Повышается риск аутоиммунной патологии, остеопороза, бесплодия. Согласно рекомендациям ВОЗ, целесообразно проводить скрининг на целиакию лиц с необъяснимыми дефицитом фолиевой кислоты, железа или В12, снижением сывороточного альбумина, необъяснимой гипертрансаминаземией, остеопорозом и остеомаляцией, рецидивирующими болями в животе или вздутием живота, рецидивирующей кожной сыпью $[4,5]$.

Представляем клинический случай поздней диагностики целиакии. Больной Ш., 46 лет, бурят, житель города Улан-Удэ, обратился к гастроэнтерологу с жалобами на ежедневные умеренные ноющие боли в эпигастрии, левом подреберье, околопупочной области, тяжесть в эпигастрии, вздутие живота, жидкий стул до 3-4 раз в день, чаще после еды, без патологических примесей, общая слабость, утомляемость, заеды в углах рта, выпадение волос, снижение веса (постепенная потеря в течение 4 лет более 10 кг), бессонница, подавленность настроения.

Из анамнеза заболевания выяснено, что с детства отмечал частые боли в животе и жидкий стул. Наблюдался с диагнозом «хронический гастрит», неоднократно лечился в стационаре с данным диагнозом. В физическом развитии от сверстников не отставал. В студенческие годы продолжали беспокоить абдоминальные боли, нарушения стула, иногда тошнота, периодически обращался к врачу, лечился амбулаторно с диагнозом «хронический гастрит». В течение последних 10 лет отмечал постепенное ухудшение состояния: усилился болевой синдром, заметно снизился вес, появились постоянные диспепсические симптомы (тошнота, вздутие, жидкий стул), выраженные и болезненные заеды в углах рта, выпадение волос. Стала нарастать общая слабость.

В течение последних двух лет состояние резко ухудшилось, появились периоды интенсивных, приступообразных болей в эпигастрии, опоясывающего характера, сопровождающиеся тошнотой, иногда рвотой, жидкий стул, 3раза госпитализирован в стационар, где лечился с диагнозом «хронический панкреатит». Принимал в стационаре и амбулаторно препараты панкреатина, ингибиторы протонной помпы, пробиотики, мебеверин, получил 3 курса 
антибактериальной терапии. Заметного улучшения состояния не наступало.

Из анамнеза жизни известно, что рос и развивался соответственно возрасту, хронические заболевания отрицает. Аллергические реакции на лекарства и продукты отрицал. Родители здоровы. Вирусным гепатитом не болел, операций не было. Не курил, алкоголь не употреблял в связи с постоянными диспепсическими симптомами. Работал инженером на авиазаводе. Не женат, детей нет. При

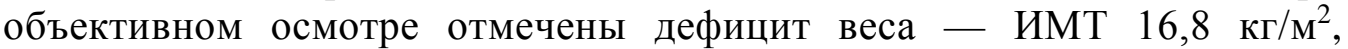
сухость кожи, заеды в углах рта. Отеков не наблюдалось. Щитовидная железа при пальпации была не увеличена. Со стороны дыхательной и сердечно-сосудистой систем при объективном осмотре отклонений от нормы не выявлено. Отмечалась обложенность языка. Живот обычной формы, в акте дыхания участвовал, при пальпации отмечалась болезненность во всех отделах, при пальпации в правой подвздошной и эпигастральной области урчание, перистальтика кишечника при аускультации была активная. Нижний край печени не выходил из-под реберной дуги, селезенка не пальпировалась. Патологические объективные симптомы были отрицательные. Стул со слов до 4 раз в день, жидкий, тип 5-6 по Бристольской шкале, иногда водянистый, иногда с примесью слизи.

В анализах крови обращали на себя внимание гипохромная анемия, незначительный лейкоцитоз, гипопротеинемия, гипоальбуминемия, снижение содержания сывороточного железа и ферритина, гипокалиемия. Острофазовые показатели крови были в норме. Печеночные тесты были в норме. Данные коагулограмм: АЧТВ 46,3 сек, MHO 4,27 ед, ПТИ 14,4\%, фибриноген 1,77 г/л. RW отр. АТ к ВИЧ отр. B копрограмме реакция на скрытую кровь отрицательная, присутствовала слизь, небольшое количество дрожжевых грибков, умеренная стеаторея и амилорея, лейкоциты 5-6 в поле зрения эпителий 1-2-0 в поле зрения; простейшие и яйца глистов не обнаружены. Бактериологический анализ кала на кишечные инфекции отрицательный. На обзорной рентгенографии органов брюшной полости отмечались признаки частичной кишечной непроходимости. При ультразвуковом исследовании органов брюшной полости выявлены признаки гипотонического желчного пузыря с выраженным застоем желчи, умеренные диффузные изменения поджелудочной железы (размеры органа не увеличены, вирсунгов проток не расширен, отмечалась неоднородность структуры за счет гиперэхогенности). По результатами ФГДС сделано заключение: эндоскопические признаки не эрозивного эзофагита, недостаточности кардии, хронического атрофического гастрита, бульбита, дуоденита. Гистологическое исследование биоптата желудка: хронический атрофический эрозивный 
гастрит антрального отдела желудка, ассоциированный с инфекцией Helicobacter pylori.

На основании вышеуказанных результатов обследования сделано заключение, что диагноз «Хронический панкреатит» не имел обоснования. В клинической картине доминировали признаки резко выраженного и прогрессирующего синдрома мальабсорбции, что диктовало необходимость выяснить причину данного состояния. В связи с началом заболевания в детском возрасте, наличием признаков мальабсорбции, гиповитаминоза, гипоальбуминемии, дефицита веса, на фоне хронической диареи, а также терапии антибиотиками в анамнезе, целесообразным было исключение клостридиальной инфекции и глютеновой энтеропатии. Исходя из этого предположения проведено дообследование: результат анализа кала на кальпротектин не превышал нормальные значения $(61,0$ мкг/г). В крови выявлены повышенные титры AEMA - 1:8 ( в норме менее 1:5), IgG AGA - 33 ед/мл (в норме до 25 ед/мл), IgA AGA - 45 ед/мл (в норме до 25 ед/мл), Anti-tTG 4,5 (в норме менее 1,0). Иммунохимический анализ кала на токсины А и B Cl.dificille был отрицательный. Выявлено в крови снижение концентрации витамина Д (12,0 нг/мл). По данным дообследования выставлен диагноз: Глютеновая энтеропатия, типичное течение, синдром избыточного бактериального роста, синдром мальабсорбции тяжелой степени, гиповитаминоз Д, железодефицитная анемия 1 степени. Депрессия легкой степени. Эрозии антрального отдела желудка, ассоциированные с инфекцией Helicobacter pylori.

Выделяют причины поздней диагностики целиакии. К ним относят ошибочные диагнозы (часто синдром раздраженного кишечника или хронический панкреатит, как у данного пациента). Затрудняет своевременную диагностику малосимптомное или бессимптомное течение, длительные латентные периоды. Многие клиницисты не подозревают о наличии данного заболевания у взрослых пациентов.

Ошибочно считалось, что целиакия - очень редкое заболевание, возникает только у европеоидов, главным образом в Европе и США, только в детском возрасте [4].

В приведенном примере у пациента отмечались типичные гастроинтестинальные симптомы, характерные для целиакии у взрослых: хроническая диарея, потеря веса, анемия, вздутие живота, утомляемость и недомогание. Также у пациента были характерные не гастроинтестинальные признаки заболевания: недостаточность железа и анемия, гиповитаминоз Д, депрессия [2].

Больному назначена аглютеновая диета, рекомендовано ведение пищевого дневника, коррекция синдрома избыточного бактериального роста, коррекция вторичной панкреатической недостаточности, препараты витамина Д. 
На фоне лечения через 3 месяца симптомы стали минимальными, отмечал прибавка веса на 6 кг, положительная динамика лабораторных показателей, а именно нормализация антиглиадиновых антител в сыворотке крови (снижение показателей AEMA до 1:5, IgG AGA до 22 ед/мл, IgA AGA до 28 ед/мл, Anti-tTG до 1,5).

Таким образом, представленный клинический случай демонстрирует разнообразие клинических проявлений целиакии, последствия поздней диагностики заболевания у взрослого пациента, эффективность аглютеновой диеты, и необходимость дообследования пациентов с возможными признаками целиакии.

\section{Литература}

1. Бельмер С. В., Гасилина Т. В. Целиакия: исходы и новые подходы к диагностике // Лечащий врач. 2012. № 8: 5. С. 10.

2. Курочкина О. К. Целиакия взрослых (клиника, диагностика, лечение): автореф. дис. ... канд. мед. наук. М., 1984. 24 с.

3. Рекомендации по диагностике и лечению целиакии взрослых / Л. Б. Лазебник [и др.]. Экспериментальная и клиническая гастроэнтерология. 2015. № 117(5). C. 2-12.

4. Практическое руководство Всемирной организации гастроэнтерологов (ВОГ-OMGE) / под ред. Дж. Баи. М., 2005. 18 с.

5. Aziz I., Sanders D. S. Are we diagnosing too many people with coeliac disease? // ProcNutrSoc. 2012. № 5(3). P. 1-7. 


\section{CLINICAL CASE OF CELIAC DISEASE IN A 43 YEAR OLD MAN}

Tatiana E. Spasova

Candidate of Medical Sciences, Associate Professor

of the Department of Outpatient Therapy and Preventive Medicine

with a course in Health and Safety

Medical Institute, Dorzhi Banzarov Buryat State University

36a, Oktyabrskaya st., Ulan-Ude, 670001, Russia

E-mail: tspasova@inbox.ru

Ekaterina D. Khaltagarova

Department of Therapy,

Medical Institute, Dorzhi Banzarov Buryat State University

36a, Oktyabrskaya st., Ulan-Ude, 670001, Russia

E-mail: tspasova@inbox.ru

A clinical case of late diagnosis of celiac disease in a 43-year-old man is presented. Symptoms of the disease were manifested from childhood, but the disease was not diagnosed. At the age of 40 years, there was a deterioration in the condition with severe manifestations of malabsorption syndrome. Celiac disease was confirmed by endoscopic examination, increased titer of autoantibodies in blood serum and positive effect of gluten diet.

Keywords: Celiac disease, gluten-free diet, antigliadin antibodies, malabsorption syndrome. 